\title{
Dental Reality and Personal Vision
}

\author{
Jean Marie Megarbane* \\ Masters Dental Clinic, Lebanon
}

Submission: February 02, 2017; Published: February 16, 2017

*Corresponding author: Jean Marie Megarbane, Lebanon Masters Dental Clinic, Al-Tawfiq Building -Zarif St, Beirut- Lebanon, Tel: 961-3250306/961-1736164; Email: jmmegarbane@gmail.com

\section{Opinion}

In the evolution of Dentistry and Oral Health, we stand at a time where we must choose whether we let the external forces shape our profession for the future or we rather have the strength and the confidence to shape it according to our principles and values.

In our knowledge, the objectives of dental therapy did not change and are still to preserve the natural dentition, maintain and improve health, function and aesthetics as well as provide replacement with implants where indicated.

Nevertheless, teeth extractions have never been as numerous and very often unnecessary despite the fact that long term studies and the consensus of the European Association for Osseo integration have shown that:

a) The tooth longevity surpasses implant longevity after 10 years of observation: survival of periodontally compromised and endodontically treated teeth (92-93\%) seems to surpass that of oral implants (82-94\%) which means that teeth should be given priority whenever possible, unless multiple risks present jeopardize their long-term prognosis.

b) As oral implants represent the last resort, they are not replacing teeth; they should replace missing teeth and treatment options other than implants should always be seriously considered.

c) The later in life the implant is installed, the further in the future, if at all, will a possible implant failure and implant loss occur.

At the same time, if we have a look at the program of most dental meetings, we will notice a definite tendency toward topics focused on aesthetics and implant dentistry with an emphasis on soft and hard tissues regeneration, these topics being supplemented by another tendency toward fast delivery and quick profit. Then a question could be raised:

"Why and how are we reaching clinical conditions requesting such advanced therapy?'”The answer is:" Excluding congenital problems and injuries, the only appropriate answer would be a certain way of dental practice.

Indeed if misdiagnosis, mistreatment and mis coordination are the major causes for tooth loss, there is also enough evidence to ascertain that implant dentistry is not the alternative or the substitute to traditional dentistry, but moreover could be the mean and only the mean in diminishing the rate of tooth loss as well as the way to maintain sound teeth and natural dentition on a long term basis.

On the other hand, concerning aesthetic dentistry and the so called "Hollywood Smile", our patients with their "I want now" are very often asking us to ignore the appropriate time necessary for a procedure but consider fast treatment before long term predictability.

a) "Should we not instead and in many instances indulge the time (give time to time) and favor predictable long term techniques rather than exploit such request for fast treatment as a way for fast profit?"

b) Are we satisfied as dentists to look at magazines covers only to find smiles that all look the same, in which one size fits everybody and encourage our patients to request copycats because it is the smile of their idols?

Are we not responsible to control and guide the mass media in educating the public and spreading the correct information rather than adverts not evidenced based.

With such observations, Aesthetics should be revisited and we would have to pay Mother Nature more respect. Aesthetics should be viewed in term of rejuvenation with a custom made approach and some consideration to the individual characteristics. It would have to make people look younger but not cloned to such extent that they lose their personality. The smile is part of the body and not a wear that changes with years along with fashion.

Finally should we not even prepare guidelines about the Ethics of Aesthetics and Implant Dentistry? The areas of management 
and marketing that have spread in all aspects of our life should be reviewed by the decision makers when it concerns the chapter of health and the time factor should also allow us to judge the criteria of success on a long term basis.

To achieve such tasks, we must have a clear vision based on our fundamental principles and shaped by our values, mission and goals. This vision should influence undergraduate and postgraduate curriculum in universities as well as continuing education for practicing dentistry. Our activities should be focused not only for "the happy few high standard specialists" who have the recipes for "all the others colleagues problems" but develop with dental associations and the universities in collaboration with the dental industry a policy and a program to determine our own purpose and professional conduct.

Dear colleagues from all over the word, providing your leadership in your fields and positions, you can help by your individual actions to make that personal vision become a reality.

Your next submission with Juniper Publishers will reach you the below assets

- Quality Editorial service

- Swift Peer Review

- Reprints availability

- E-prints Service

- Manuscript Podcast for convenient understanding

- Global attainment for your research

- Manuscript accessibility in different formats

( Pdf, E-pub, Full Text, Audio)

- Unceasing customer service

Track the below URL for one-step submission https://juniperpublishers.com/online-submission.php 